\title{
Trauma Transmission and Sexual Violence
}

This book grapples with the potential impacts of collective trauma in war-rape survivors' families. Drawing on interethnic and intergenerational participatory action research on reconciliation processes in postconflict Bosnia-Herzegovina, the author examines the risk that female survivors of war-related sexual crimes, now mothers, will breed hatred and further division in the postconflict context. Showing how the historical trauma of sexual abuse among survivors affects the ideas, perceptions, behavioral patterns, and understandings of the ethnic and religious 'Other' or perpetrator, the book also considers the influence of such trauma on other attitudes rarely addressed in peacebuilding programs, such as notions of naturalized gender-based violence, cultural scripts of sexuality, and support for dangerous or violent aspects of the patriarchal social order. It thus seeks to sketch proposals for a curriculum of peacebuilding that takes account of the legacy of war rape in survivors' families and the impact of trauma transmission. As such, Trauma Transmission and Sexual Violence will appeal to scholars of politics, sociology, and gender studies with interests in peace and reconciliation processes and war-related sexual violence.

Nena Močnik is a researcher at the CY Cergy-Paris Université, France, and the author of Sexuality after War Rape: From Narrative to Embodied Research. 


\section{Routledge Research in Gender and Society}

\section{Reframing Drag}

Beyond Subversion and the Status Quo

Kayte Stokoe

\section{Rape in the Nordic Countries}

Continuity and Change

Edited by Marie Bruvik Heinskou, May-Len Skilbrei and Kari Stefansen

\section{Refracting through Technologies}

Bodies, Medical Technologies and Norms

Ericka Johnson

\section{Young, Disabled and LGBT+}

Voices, Identities and Intersections

Edited by Alex Toft and Anita Franklin

\section{Transdisciplinary Feminist Research}

Innovations in Theory, Method and Practice

Edited by Carol A. Taylor, Christina Hughes, and Jasmine B. Ulmer

88 Identity, Belonging, and Community in Men's Roller Derby

Dawn Fletcher

\section{The Gender-Sensitive University}

A Contradiction in Terms?

Edited by Eileen Drew and Siobhan Canavan

90 Trauma Transmission and Sexual Violence

Reconciliation and Peacebuilding in Postconflict Settings

Nena Močnik

For more information about this series, please visit: https:/www.routledge.com/ sociology/series/SE0271 


\section{Trauma Transmission and Sexual Violence \\ Reconciliation and Peacebuilding in Postconflict Settings}

Nena Močnik 
First published 2021

by Routledge

2 Park Square, Milton Park, Abingdon, Oxon OX14 4RN

and by Routledge

52 Vanderbilt Avenue, New York, NY 10017

Routledge is an imprint of the Taylor \& Francis Group, an informa business

(C) 2021 Nena Močnik

The right of Nena Močnik to be identified as author of this work has been asserted by her in accordance with sections 77 and 78 of the Copyright, Designs and Patents Act 1988.

All rights reserved. No part of this book may be reprinted or reproduced or utilised in any form or by any electronic, mechanical, or other means, now known or hereafter invented, including photocopying and recording, or in any information storage or retrieval system, without permission in writing from the publishers.

Trademark notice: Product or corporate names may be trademarks or registered trademarks, and are used only for identification and explanation without intent to infringe.

British Library Cataloguing-in-Publication Data A catalogue record for this book is available from the British Library

Library of Congress Cataloging-in-Publication Data A catalog record has been requested for this book

ISBN: 978-0-367-22214-7 (hbk)

ISBN: 978-0-429-27379-7 (ebk)

Typeset in Times New Roman

by Deanta Global Publishing Services, Chennai, India 


\section{Contents}

Preface vii

1 I will not raise my child to kill your child 1

Introduction 1

2 Edifying ethnography and a voice-in-between

A methodological remark 12

Notes 24

Bibliography 24

3 Social (ab)uses of war-related sexual trauma

Survivor-centered trauma healing as institutional inhibition to social recovery 26

Narrated silences and the (ab)use of collective memory in sexual scripts 36

Note 49

Bibliography 49

4 Mothering with the trauma of war rape

(Il) legitimate motherhoods 53

Teaching trauma-free sexual scripts in traumatized homes 65

A survivor, a mother: The fear of fostering hatred 83

Notes 95

Bibliography 96

5 Intergenerational effects of trauma transmission and continuation of violent sexual culture

Between forgiveness and rage, forgetting and transmitting 101

Trauma transmission, collective memory, and the continuation of (sexualized) violence 118

Note 131

Bibliography 131 
vi Contents

6 War-rape legacies: Transmission, agency, transformation 134

Toward the changing paradigms in healing from trauma:

Sociotherapy and trauma of war rape as social responsibility 134

Transmitted traumas, chosen memories 143

War-rape legacies in (peace) education 154

Notes 167

Bibliography 168

7 Survivors and postwar youth in intergenerational dialogue to prevent the transmission of sexual traumas

Index 


\section{Preface}

This research is based on ethnographic work in Bosnia-Herzegovina, conducted between 2011 and 2019. It combines data collected from the group interactive workshops, individual conversations, semistructured interviews, spontaneous gatherings, participation with observation, and my own pedagogical practices in prevention of (sexualized) violence.

Throughout the book I refer to mother-survivors simply as 'survivor' if not otherwise stated. In order to minimize the narrative fetishism and to protect people that participated in the research, I provide initials of the first name, sometimes age, and the geographical region. Should the reader require more data or information on ethnographic content, she can contact the author directly.

For the scope of this book, I refer to heteronormative families that consist of a biological mother, father, and children. I do not ignore or deny other forms of families and family relations, nor diverse sexualities and gender spectrum. As my ethnographic work did not include any form other than the one mentioned, I wanted to avoid generalizing or drawing conclusions without any concrete research evidence. However, I hope that this book, despite its limitations, can be a departure point to conduct more research on trauma transmission with all forms and shapes of families in diverse sociopolitical contexts. 


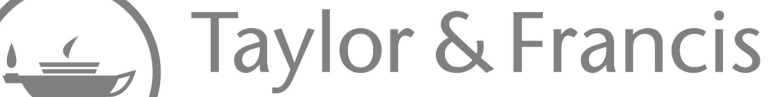

Taylor \& Francis Group

http://taylorandfrancis.com 


\section{I will not raise my child to kill your child}

\section{Introduction}

The beginnings of this book go back to 2015, to a village in central BosniaHerzegovina when I was leaving the country after finalizing my previous research. I was visiting women with whom I had worked for half a year to thank them for a fruitful collaboration and the mutual trust, exchanges, and conversations. I traveled with one of them, whom I will call Alma, to a village where another woman that I had worked with, here called Senka, lived with her husband and two daughters. When we arrived, she had just come from the hen house after finishing her morning routine and was changing from her plastic boots to comfortable slippers in front of the house. She warmly invited us to enter, and as is very common in the region, we gathered on a couch, sipping coffee and snacking on wafers. Her husband brought an orangeade from the cellar and then, after briefly shaking our hands, left the house. It was late morning, and the two daughters, aged 13 and 9, were in school. Glancing at the framed pictures of the two girls, Alma expressed how lucky Senka was to have two daughters, while she - although still thankful for her children had two boys. "They get to help you with your chores, and you have nothing to worry about when you get old as the girls will take care of you," said Alma. "I have worries, more every year," responded Senka. "Every time they are about to return after dawn, I fear they will get attacked. You know how men are here and what they want." This conversation continued back and forth between them, but they never directly addressed their own experiences with men. Yet the shadows of their memories were somehow present in the room.

Signaling that she wanted to get away from the topic, Alma lit another cigarette and, while exhaling, turned to Senka. "I don't know what kind of mother raises her son to go against the woman. You know that I am not raising my boys to hurt, let alone kill, your girls." After a short pause, she added, "Or any girl, ever." It was hard for me to understand if her expression was anger, guilt, blame, or frustration. But it seemed important that she gave her word to Senka to be a mother who would never raise a murderer. Or a rapist.

For a moment, there was a feeling of sudden estrangement, a stop in time. Perhaps there was the realization, a brief reflection of the burden of a survivor, now mother, and her everyday preoccupation with how to prevent the transfer of 


\section{I will not raise my child to kill your child}

this burden of trauma, to her offspring. If they were to have met outside of the house, they would perhaps easily agree that they understand each other because they share the same memory of the war, because they both had the same experience. They were both raped. Now, they shared another similar role - that of mother. Yet one was a mother to boys; the other was a mother to girls. What they feared was that one of them would raise victims; the other would raise perpetrators. For both, there was perhaps a sense of responsibility and a feeling that it was all about them, the mothers. Perhaps the onus was on them to raise a generation that would not be haunted by the past but, rather, would learn from their mothers' pasts and never repeat those circumstances in the future. This burden of a responsibility born of their pasts, although mostly uncommunicated in a cognitive way, is real for not only these two women but also for many rape survivors who are now mothers. What do I tell my kids about my past? How do I share with them my story but keep them from feeling rage? Or disgust for me? Not to shame me or abandon me?

Despite rich feminist scholarship and widespread pedagogy, in most of the world in the twenty-first century, mothers are still the main pillars raising the family. While giving their best through mothering, many women have to cope with their own traumas in order to spare their descendants the hostile results of intergenerational effects from the trauma transmission. Both Alma and Senka survived captivity, sexual violence, and rape, and, afterward, both were internally displaced. They each remarried and started families but were never able to return to their places of origin.

I had a chance to meet them at their regular occupational therapy group, where they and other survivors meet to knit and spend time together. One of them is receiving financial compensation as an officially recognized survivor; the other is unemployed and still in the process of obtaining this status. In their aspirations for restorative justice, they have both contributed to different state and international institutions by giving their testimonies. Both have collaborated with individual researchers and journalists. In addition, they regularly attend protests, sign petitions, and have been otherwise proactive in giving a voice to the issues of the stigma, public recognition, and social ostracism of women who are war-rape survivors.

Regardless of this activism, mothering is their priority, a part of their life where they feel they have agency. Sometimes, they act as if the lives they led during the war have been frozen in the past for years. It is true that in those frozen years, they were assigned new roles that, in fact, radically changed their life paths and perhaps forever labeled them as survivors of war rape. But becoming a good mother in the aftermath, with the power to teach their kids what they perceived to be good values, useful skills, and vital knowledge about the world, was evidence that a "normal" life had returned. Before the war, many had seen their future in mothering. For those who eventually did become mothers, despite the violent interruption of the war and despite the devastating damage to their sense of self, becoming a mother after the war was a sign of overcoming the past. For some, it was proof of their survival. 
Today, Senka and Alma, and many other mothers I have met on my research journey, fully indulge in mothering, keeping their kids and grandkids at the center of their attention with a determined mission to teach them what their mothers taught them - to be not just good humans but also good husbands and wives, and, for their daughters, to become good mothers. What was not expressed as often by those who had sons was raising their boys to be good fathers. More often, they emphasized that they hoped to see their sons become fair and righteous men who do not steal or beat their wives and who do not drink or participate in murky business dealings.

Returning to certain traditional values and lifestyles, taking over the social roles that they are familiar with, is a prevalent trend for many postconflict societies. This return to the familiar not only symbolically denies that the war ever happened but also offers safety and known and predictable life situations. After spending years under chaotic and anarchic circumstances of war, traditional cultural patterns help survivors regain a sense of control over their lives, and this becomes particularly overt through mothering. Most of the mothers in peripheral regions where I conducted the majority of my ethnographic research apply the traditional hegemonic patriarchal rules in their maternal practices. Despite their war rape experiences, they feel that they have to fulfill their duty as mothers, and the role came effortlessly to them soon after the war. For some, motherhood was a revival of sorts, a return to normal. Others believe that it helped them move on and heal. Some did not want to look back and wanted to focus only on the future and the well-being of their children. Still others use the past to spur their resistance which they pursue for the sake of their children and a better future.

But surprisingly, very few researchers have paid attention to how mothersurvivors of war rapes navigate life between their own process of healing from trauma, their struggle for restorative justice, and their role as a mother, especially as it pertains to socialization in terms of gender and sexuality. While the subject of their children continually arose in conversations and encounters I'd had with survivors since the beginning of my research back in 2011, it had only recently occurred to me how deeply their experience of war rape was embedded in their mothering when it came to socialization about gender roles and sexual scripts. Until that very moment when I was listening to Alma and Senka, I had mostly thought of survivors as survivors, encompassing how they embraced (or not) the experience of war rape, how they co-created the collective memory, how they established new identities in the aftermath of the war, and how the healing process helped them reintegrate into the broader society. Only rarely had I reflected on the ways each woman's violent past interlaced with the role of mother in the aftermath of the war and the unstable present day of their children and grandchildren.

In the aftermath of the war, motherhood has been recognized in today's collective memory of Bosnia-Herzegovina as mainly (although not exclusively) in two contexts. When referring to mothers, one will most probably first come across the Mothers of Srebrenica, a grassroots movement of mothers searching for their loved ones and demanding the truth about, and recognition of, genocidal crimes perpetrated against their family members, particularly their male family 
members: sons, husbands, brothers, and fathers. Although testimonies about sexual crimes and violence have also been reported in relation to the Srebrenica massacre, and several scholars have critically examined the abuse of power and sexual exploitation of local women by Dutch UN peace-keepers, the question of rape has been somewhat alienated from the main focus of the group. In fact, I have personally experienced avoidance of this topic when I sought more evidence on war-rape survivors among mothers from Srebrenica. While one of the surviving mothers shared with me her story of being asked for sexual and emotional compensation in exchange for some essential household goods she needed after being internally displaced, she then changed the topic whenever I tried to bring sexual violence and motherhood together in the same conversation.

However, interest has recently begun to increase on a national and international level with regard to mothers who gave birth as a direct consequence of war rape. Those women and the stigma related to this issue came to prominence in great measure because of help from their now adult children, many of whom decided to engage in activist work and speak openly about issues related to the long-term legacy of war rapes. Contrary to the mothers of Srebrenica, who committed their lives to searching for the remains of their lost sons, mothers of children born as a result of war rape have struggled with losing their children by giving them away at birth. In a culture where women can only be fully accomplished through acts of self-sacrificing caring and nurturing, giving away an unwanted child is yet another trauma for the war-rape survivor to carry with her in the aftermath. The struggle of those mothers in accepting the guilt and stigma is constantly reinforced through socially favored myths of ideal motherhood, wherein a mother, the "primal giver of life," subjugates her own needs to those of her offspring. While these traumas are socially inflicted and perpetuated, most of the mothers are left to their own devices to cope with posttraumatic stress disorder (PTSD) symptoms and taking care of their own healing and social reintegration.

Unlike the mothers from Srebrenica, who after years of efforts to gain restorative and retributive justice started to receive recognition, respect, and honorable status in the international community, mothers of children conceived through war rapes remain in the shadows. Other than these two mothering experiences related to the war, little to nothing is said about survivors who became mothers only in years after the war. While they perhaps did not lose their children in combat nor had to decide whether to keep or give away the "perpetrator's" child, they also carry the burden of traumatic experiences of war rape and sexual violence. But all of those mothers, in one way or another, question how to incorporate their war rape experience into mothering in such a way that prevents the transmission of destructive emotions like rage or hatred but, rather, results in their children giving them loving support and safe shelter but also working toward reconciliation and sustaining peace in the aftermaths of the conflict.

A common characteristic in the narratives of mothering experiences from women who were sexually traumatized during the war is their struggle between two seemingly incompatible identities, a war-rape survivor, on the one hand, and a mother, on the other. Despite these split identities, for many women, mothering 
has been a crucial step toward embracing healing from the trauma. It has helped many survivors to make sense of the aftermath of the war and provided them with a reason to move on and live again. The decision to focus on mothering after a war rape experience often presents a survival strategy through which one is able also to postpone the systematic and intentional process of healing and coming to terms with the trauma. By being fully occupied with taking care of children, and later, grandchildren, survivors have been able to suppress their experience of rape for many years. For those who suppressed these traumas, did they succeed in protecting their offspring from potentially transmitted trauma? Did any of the children or grandchildren suspect or feel something in their mother's past and search for more information? Was suppressing the trauma beneficial for the descendant's future?

Although being haunted by the legacy of rape and facing difficulties in denying their personal history was part of the everyday struggle, most of the survivors I spoke to had never disclosed their experience to their children. In the years immediately following the war, the sociopolitical denial of war rapes was so prevalent that disclosure was impossible. Furthermore, many survivors were preoccupied by the survival of their loved ones first. They were busy with rebuilding, emotionally and physically, their now destroyed world, and, at the same time, they feared stigmatization and being abandoned. Unfortunately, this was what actually happened to some of the survivors who were courageous and trusting enough to hope for the support and understanding of their families. But it happened also to some of the survivors who faithfully believed that silence would help them bury their past and the trauma and live only with their postwar newly attained role of mother. After years had passed, the tool of silence had bounced back and become so defining for their identity that today, although there are more opportunities and better chances for disclosure, some survivors cannot establish their identities and social relationships outside of the social expectation of silent/silenced survivor.

I address this in the very beginning of the book through the prism of "narrated silences," as I believe that this intentionally created and systematically reproduced discursive mechanism attached to the experience of the survivors has had an important influence on the production of knowledge and the representation of survivors that we have today. But in addition, it has influenced how we approach incorporating questions about the legacy of war rape in today's (peace) education. Societal preferences for silence, with the implication that silence is the most dignified position for survivors, has allowed everyone in society, particularly survivors, to confirm that opening up to their children is not going to be beneficial for anyone. Narrated silences help with the reasoning that sharing testimonies with survivors' family members only causes the children to have confused feelings toward their mothers and risks alienation of the mother-child relationship or creates mistrust of maternal authority. In addition, many believe that the silence in fact protects children from the toxic legacies of the violent past. While sharing the story would perhaps ease the survivor's pain, it also risks the pain of becoming owned by their children. At worst, the pain might get turned into revenge fantasies and biases that could lead to intergroup hatred with ethnic profiling based on the 


\section{I will not raise my child to kill your child}

roles that the ethnic groups played in the war and the postwar criminal proceedings: those of survivors or of perpetrators.

The narrated silences also explain the paradoxical social statement about war rapes today: while survivors are supposedly silent, the persistent resistance of local and international activists, scholars, artists, and engaged civic populations have made the crime of war rape visible and widely discussed. The rights and political demands of women survivors are being slowly, yet increasingly, met, and there is social progress against denial and stigmatization. The topic is brought to public attention through street protests, events, and public commemorations. For the descendants and postwar generations in general, this means that no matter how strong the intentions originally were to ensure that the silence remained unshattered and unbroken and how persistently these mothers kept their mouths shut, when growing up in today's Bosnia-Herzegovina it is almost impossible to not learn about war rapes and the long-term trauma of survivors. Not only are today's postwar generations exposed to the continuous flow of information on social media but also the developments in memory politics have made active participation much easier and activities related to this topic more accessible. While I believe that children are not merely passive receivers of their parents' collective memory, the ethnographic evidence for how families can contribute in either ideological consumption or critical learning when dealing with violent pasts is still vague and sometimes discrepant.

Despite their different experiences, understandings, and perceptions of surviving war rape, most of the mother-survivors have never been able to fully recover from the trauma, and as a result, the trauma has, despite their efforts to the contrary, become persistently present within their families. No matter how great the joy of seeing children and grandchildren grow and prosper in their lives, the burden of surviving war rape and how to share this with their kids remained. So the stigma attached to survivors of war rape remains and is passed on not only by one survivor to another but also from one generation to another. From the time that girls are born, we are told that we are not safe. You know that you are at risk because of your gender and are taught that it is your sexuality that makes you vulnerable. If most of our mothers told us this because their mothers had told them the same, what do mothers who were not told the same story but experienced it in their own bodies tell us? If our identity as women includes the shared experience of fear of potential male inflicted sexual violence, how do survivors of war rape, who are victims of this in a very immediate sense, incorporate these experiences into their mothering practices? How do survivors for whom justice has never been done and whose attackers have never been prosecuted manage to negotiate their complex emotions, calls for forgiveness, and the nurturing of a positive attitude toward reconciliation?

The importance of intergenerational dialogue has been widely promoted, but in practice, it is hard to get parents and grandparents on board when they have never had access to effective methods of healing their own traumas. In the case of survivors of war rape, this is made even more difficult due to mothers whose experiences are hidden behind the wall of silence and who have not openly shared 
their experiences, even with other women who experienced the same trauma or in spaces where they could receive support services. I remember one of the first encounters I had with a group of women when I was presenting the purpose of the research. The leader shut me down, saying, "No woman has ever spoken to their kids, so they have nothing to say in this research." However, with persistence and by posing semi-rhetorical questions, I asked them, "But would you like to share with your kids what happened to you? Do you think this would be something important for you?" After a moment, the silence broke, and I was unable to catch everything they said because the women were talking over each other. It was clear that, in fact, those women had a lot to say in this research. There was a need to have space to talk about this, and so we started to meet.

Researching and understanding the impact of these mothers on their children and grandchildren in a cultural context where women still represent one of the most important pillars of the family seems to be of the utmost importance prior to embarking on any efforts toward peace education. Years ago, when I was engaged in various multicultural and peace education programs as a youth worker, I began to question our time-limited impact during the occasional workshops and summer programs in comparison to that of family members and peers who remained in a young person's life long after our educators' intervention was over. Young people would stay in our programs for a week or two as we covered a hyperenergized and optimistic schedule prioritizing peace, tolerance, diversity, and equality. Afterward, they would return to the close-knit environments of their families, schools, and peers. But how sustainable can such youth peace programs be in postconflict zones if we do not consider the threat of trauma transmission in families? While a critical approach to dealing with the ideologically loaded history curricula in the postwar context is now a preoccupation of many educators and scholars, in most cases, family is still the first and most important factor in socialization. It is important for all of us who work in education to learn how to cope with the transmitted, learned, and internalized war legacies that children bring to the schools.

This book grapples with the complex nexus of the potential impacts of collective trauma in war-rape survivors' families in the midst of reconciliation processes in postconflict Bosnia-Herzegovina. With the illustration of ethnographic data, I debate arguments and restraints regarding evidence of risk, whereby survivors of war-related sex crimes who are now mothers might become breeders of hatred and further division in the postconflict context. In the first part of the book, "Social (Ab)uses of War-Related Sexual Trauma," I introduce the idea of narrated silences mentioned earlier as part of the collective memory of survivors and how this has manifested in social realities, values, and relationships. This introduction presents the reader with a further understanding of how, for many survivors, silence has been argued to be a protective mechanism and a conscious act of not telling in order to avoid stigma or vicarious trauma for their family members, especially children. In this way, the silence of survivors becomes a conscious act intended to prevent trauma transmission. However, the mass rapes in BosniaHerzegovina are now a public fact, notwithstanding the number of survivors who 


\section{I will not raise my child to kill your child}

remain silent. If not directly from their family members, postwar generations can obtain the stories about these events from the media, their peers, and their friends. Thus, narrated silences might operate as a crucial and sometimes the only source of information for those youngsters to access the stories of their parents. As such, they can intervene powerfully in the spheres of informal education and socialization. They not only inform about the past but, more importantly, they imply how to incorporate the lessons and experiences from the past into their existing sets of values, viewpoints, and cultural (sexual) scripts. For this reason, any recreation and/or reproduction of narratives that can communicate the normalization of harmful social relations, dynamics, or processes holds us as creators responsible for fortifying the efforts of critical mediation and the reading of constructed social realities.

The second part of the book, "Mothering with the Trauma of War Rape," shows, as mothers and grandmothers, women remain a primary pillar of the foundation of family and home as they organize daily life and build relationships with children and grandchildren. Despite much excellent work on the psychosocial repercussions of war trauma, displacement, and the postwar mother-child dyad, little is known about how these factors transfer collective memory in terms of continuous hatred and a violent (sexual) culture. Based on these premises, this part of the book looks more closely at the family dynamics of women survivors of war rape and war-related sexual violence and focuses specifically on the potential correlations between child-rearing, trauma, and the transmission of hatred as a response to frustrating postwar injustices. Furthermore, it attempts to answer the question of the impact of a traumatic family past on the children's upbringing, particularly in the understanding of gendered roles and the reestablishment of normative sexuality, which as long as it is based on patriarchy, is arguably inherently violent. I ask, what effects do feelings of hatred and revenge toward the ethnic other have on boys, and what effect does the display of determined victimhood have on girls/victims, especially the gendered idea of powerlessness, innocence, and shame and, hence, the idea that women are inherently rapable?

The third part of the book, "Intergenerational Effects of Trauma Transmission and Continuation of Violent Sexual Culture," moves away from the intimate family environment and focuses on wider questions regarding the willingness and urgency to forgive in order to reconcile. Previous research has found the act of forgiveness to be crucial for releasing feelings of anger and revenge toward perpetrators. The act of forgiveness can promote a positive view of reconciliation and lead to postconflict stability; however, the question remains whether real forgiveness is possible before justice is achieved. As those chapters illustrate, most of the survivors continue to fight for justice. At the same time, forgiveness given before perpetrators are prosecuted might lead to further denial as well as forgetting. I reflect on knowledge, emotions, beliefs, and values that second and third generations have potentially internalized, either consciously through conversations or unconsciously through random assumptions and individual searches for information. I attempted to show also how transferring traumatic 
memory that is derived from war-related sexual violence differs importantly from other war- or genocide-related traumas.

The last part of the book, "War Rape Legacies: Transmission, Agency, Education," presents how different social actors with a specific focus on youth have taken over the processes of the long-term anti-stigmatization of war-rape survivors by incorporating new knowledge and generationally specific narratives on gender, sexuality, and violence. In introducing several projects, I question why specifically peace education in the region today focuses on enhancing interreligious and interethnic dialogues but rarely focuses on identity in relation to sexuality and gender. Furthermore, evidence shows that peace education is not intergenerational when it comes to mother-survivors, as they merely participate in one of the youth programs and almost never let their struggles for justice intersect with the broader field of peace education. This applies as well to the questions related to trauma transmission in families - while it gets addressed as a potential risk and a threat, peace education programs do not really focus on working with mothers and mothering to deal with this.

Before focusing on the main themes of the book, I also wanted to start with a brief reflection on my own voice and methodologies used throughout the ethnographic work. The research approach, ethical concerns, and communication with research participants before, during, and especially after the research, are always my greatest concern. Questioning, adjusting, testing, and evaluating new research approaches has, for me, always been of equal importance as the research theme itself. As I strive to engage more than a traditional researcher, I am always excited to understand the variety of social practices used, for example volunteering with survivors or teaching in summer school with young people in the region, and I see them as an opportunity to reflect on those activities as data collection experiences. Exploring diverse methodologies is, for me, important because I do not think that academic language always translates into fulfilling the immediate needs of research participants. This concrete research, for instance, cannot bring the immediate change that people with whom I collaborate sometimes want in return for their contribution. When you have nothing concrete to offer in return - such as therapy, changes to legislation, the advancing of survivors' rights, or similar actions - it is unreasonable to expect that participants will feel the same level of enthusiasm for participating in a new piece of research as you do. If a survivor has participated since the end of the war in a variety of investigations, reports, networking, and so forth in the belief that life will finally bring her some type of compensation for what she lost and how she suffered, and then finds herself 25 years later still living in the same mostly impoverished circumstances, it is understandable why her first and/or only reaction to a proposed new research project is exhaustion and annoyance. However, I am happy to note that most of the survivors have been motivated to collaborate in this project as they have recognized the importance of incorporating legacies of war-related sexual violence and transmitted traumas from mothers, in peace education, and consequently how with the help of survivors we can develop intergenerational education to 
break down stigmas related to sexuality and gender and the cycles of historically repeating violence.

For young people, however, talking about a war that happened some ten years before they were born is a double-edged sword. Some of them are very interested in the topic in the sense of avoiding history repeating itself and looking positively to a future of peace and coexistence. These young people attend summer schools and peace education programs to learn ways of promoting reconciliation and social reconstruction. While discourse analysis of the (social) media might show a much less optimistic prognosis for sustained peace in the country, such programs are always an inspiring and motivational force for every peace educator. However, in between these two edges, there is a group of young people who feel indifferent and perceive the topic as irrelevant. They feel this was not their war and, hence, they want nothing to do with it. And I believe this is a fully legitimate and relevant position as any other.

We could learn from the extensive scholarship on trauma transmission in the case of the Holocaust that the third generation becomes particularly vulnerable to the influence of the violent histories of their grandparents, yet I remain puzzled as to whether peace education should help to suppress the pain and trauma of the survivors until they pass away and then construct memories that their descendants will be able to live with, or if we should persist in digging into these personal histories and exploring the kinds of educational and community projects that we should be working on in order to process these emotions and traumas constructively. What kind of pedagogy do we need to develop and employ to ensure that descendants will not be afraid to dig into this long-buried pain but, rather, will accept it as a part of the intergenerational story that we want to learn from but not live again?

This is where my story and my passion come in. I am not a survivor nor a mother. I am writing this book as an educator in the field of humanities and social sciences, with a specific focus on the prevention of (sexualized) violence. Through my teaching, I emphasize the importance of historical legacies in contemporary practices of (sexualized) violence and (gender-based) oppression. Even if they were not directly exposed to war, a student's family history is often reflected in their values, viewpoints, openness, fears, frustrations, and unease. Having the privilege to teach in diverse contexts all around the world, I feel anxious entering a class, knowing that there may always be a student who grew up in a family that suffers from any type of collective trauma. There has been so much collective/ political violence and so many mass atrocities in the twentieth and twenty-first centuries that it is almost impossible to be socialized without any reference to the traumatic memory. I was surprised myself in conversations with my father, for instance, himself part of the third post-World War II generation, full of anger and bitterness about current political situations. And I discovered, step-by-step, that it was a reflection of his family traumatic history.

It is not comfortable to commit to the deconstruction of what our students bring to the classroom; it is not comfortable to question the traumatic burdens of our parents and how this (unconsciously) shapes our values, beliefs, and the 
relationships we establish with others. Despite theoretical and empirical attempts at critical pedagogy, institutional education still avoids perceiving and supporting teaching as a mutual (emotional) exchange that includes unpacking the baggage that we bring into our shared spaces. I believe teaching peace and social coexistence in the isolated, safe space of the classroom, as if there were no memory and heritage attached to it, is not sustainable. I would like to see unpacking happening in my classroom and in the classrooms of my fellow teachers. But before we can do this, we need to have a conversation with those who pack the baggage. I decided to ask mothers first. It was not necessarily the best, let alone easiest way to find these answers, but it certainly took me on an exciting and insightful journey. 


\section{Bibliography}

Arendt, H. 1985. The human condition. Chicago: University of Chicago Press.

Bell, H., Kulkani, S., and Dalton, L. 2003. "Organizational prevention of vicarious traumatization." Families in Society 84 (4): 463-470.

Bryman, A. 2016. Social research methods. 5th ed. New York: Oxford University Press.

Coles, J., Astbury, J., Dartnall, E., and Limjerwala, S. 2014. "Qualitative exploration of researcher trauma and researchers' responses to investigating sexual violence." Violence Against Women 20 (1): 95-117.

Cunningham, M. 2004. "Avoiding vicarious traumatization: Support, spirituality, and self-care." In N. Boyd Webb (Ed.), Mass trauma and violence: Helping families and children cope (327-346). New York: Guilford Press.

Dickson-Swift, V., James, E. L., and Liamputtong, P. (Eds.). 2008. Undertaking sensitive research in the health and social sciences: Managing boundaries, emotions, and risks. Cambridge, UK: Cambridge University Press.

Frank, W. A. 1995. The wounded storyteller: Body illness and ethics. Chicago: University of Chicago Press.

Friederic, K. 2010. "Notes from the field: The negotiation of boundaries: Anthropological clichés, witnessing and honest self-work." Arizona Anthropologist 20: 81-88.

Haidu, P. 1992. "The dialectics of unspeakability: Language, silence and the narratives of desubjectifictaion." In S. Friedlander (Ed.), Probing the limits of representation: Nazism and the "final solution" (277-299). Cambridge, MA: Harvard University Press.

Jackson, M. 2002. The politics of storytelling: Violence, transgression, and intersubjectivity. Copenhagen: Museum Tusculanum Press.

Knight, C. 2010. "Indirect trauma in the field practicum: Secondary traumatic stress, vicarious trauma, and compassion fatigue among social work students and their field instructors." Journal of Baccalaureate Social Work 15 (1): 31-52.

Knight, C. 2013. "Indirect trauma: Implications for self-care, supervision, the organization, and the academic institution." The Clinical Supervisor 32 (2): 224-243.

Laas, O. 2016. Toward truthlikeness in historiography. European Journal of Pragmatism and the Writing of History 8 (2): 1-29.

Maggio, R. 2014. The anthropology of storytelling and the storytelling of anthropology. Journal of Comparative Research in Anthropology and Sociology 5 (2): 89-106.

Mladjenović, L. 1999. "Caring at the same time: On Feminist politics during the NATO bombing of the Federal Republic of Yugoslavia and ethnic cleansing of Albanians in Kosovo." In S. Meintjes (Ed.), The aftermath: Women in post-conflict transformation (172-183). London: Zed Books. 
Munslow, A. 2017. "History, skepticism and the past." Rethinking History 21 (4): 474-488. Rorty, R. 1979. Philosophy and the mirror of nature. Princeton: Princeton University Press. Saakvitne, K. V. 2002. "Shared trauma: The therapist's increased vulnerability." Psychoanalytic Dialogues 12 (3): 443-449.

van der Merwe, A. and Hunt, X. 2019. "Secondary trauma among trauma researchers: Lessons from the field." Psychological Trauma: Theory, Research, Practice, and Policy 11 (1): 10-18.

Adorno, T. 1949. Gesellschaftstheorie und Kulturkritik. Frankfurt am Mein: Suhrkamp.

Agathangelou, A. M. 2000. "Nationalist narratives and (dis)appearing women: State sanctioned sexual violence." Canadian Woman Studies 19 (4): 12-21.

Akman, K. B. 2015. "Sociotherapy as a contemporary alternative." Bangladesh E-Journal of Sociology 12 (1): 9-16.

Allen, B. 1996. Rape warfare: The hidden genocide in Bosnia-Herzegovina and Croatia. Minneapolis: University of Minnesota Press.

Amnesty International. 1993. Bosnia-Herzegovina: Rape and sexual abuse by armed forces. London: International Secretariat.

Anderson, I. and Doherty, K. 2008. Accounting for rape. London: Routledge.

Bar-On, D. 1996. The indescribable and the undiscussable: Reconstructing human discourse after trauma. Budapest: Central European University.

Barry, K. 1979. Female sexual slavery. Englewood Cliffs, NJ: Prentice-Hall.

Berry, M. E. 2017. "Barriers to women's progress after atrocity: Evidence from Rwanda and Bosnia-Herzegovina." Gender and Society 31 (6): 830-853.

Bird, F. B. 1996. The muted conscience: Moral silence and the practice of ethics in business. Westport, CT: Quorum Books.

BIRN Justice Report. 2014. “Documentary ‘Silent Scream’ shown in Sarajevo.” Available at http:/www.balka ninsi ght.com/en/artic le/birn-docum entar y-silen t-screa m-premi ers-in-saraj evo (accessed 18 November 2019).

Blanchot, M. 1986. The writing of the disaster. London: University of Nebraska Press.

Blanco, F. and Rosa, A. 1997. "Dilthey's dream: Teaching history to understand the future." International Journal of Educational Research 27 (3): 189-200.

Burt, M. R. 1980. "Cultural myths and supports for rape." Journal of Personality and Social Psychology 38 (2): 217-230.

Caruth, C. 1995. "Recapturing the past: Introduction." In C. Caruth (Ed.), Trauma: Explorations in memory (151-157). Baltimore: Johns Hopkins University Press.

Clark, N. J. 2016. "Working with survivors of war rape and sexual violence fieldwork reflections from Bosnia-Hercegovina." Qualitative Research 17 (4): 424-439.

Cliff, M. 1978. "Notes on speechlessness." Sinister Wisdom 5 (Winter 1978): 5-9.

Cohen, S. 2001. States of denial. Knowing about atrocities and suffering. Cambridge: Cambridge University Press.

Crocker, J., Major, B., and Steele, C. 1998. "Social stigma.” In S. Fiske, D. Gilbert and G. Lindzey (Eds.), Handbook of Social Psychology (504-553). Boston, MA: McGraw-Hill.

Culbertson, R. 1995. "Embodied memory, transcendence, and telling: Recounting trauma, Re-Establishing the Self." New Literary History 26 (1): 169-195.

Danieli, Y. 1998. "Introduction: History and conceptual foundations.” In Y. Danieli (Ed.), International handbook of multigenerational legacies of trauma (1-17). New York: Plenum.

Davies, W. 2017. "On mental health, the royal family is doing more than our government." Available at https://www.theguardian.com/commentisfree $/ 2017 / \mathrm{apr} / 20 / \mathrm{m}$ (accessed 8 July 2019). 


\section{Bibliography}

Delić, A. and Avdibegović, E. 2016. "Shame and silence in the aftermath of war rape in Bosnia and Herzegovina: 22 years later." Available at https://www.researchgate.net $/ \mathrm{p}$ ublication/293815848_Shameand_Silence_in_the_aftermath_of_War_Rape_in_Bosni a_and_Herzegovina_22 years later (accessed 5 November 2019).

Drakulić, S. 2001. As if I am not there. London: Hachette Digital.

Edelson, M. 1970. Sociotherapy and psychotherapy. Chicago: University of Chicago Press.

Egan, K. 1997. The educated mind: How cognitive tools shape our understanding. Chicago: University of Chicago Press.

Eyerman, R. 2004. "The past in the present culture and the transmission of memory." Acta Sociologica 47 (2): 159-169.

Felman, S. and Laub, D. 1991. Testimony: Crises of witnessing in literature, psychoanalysis and history. New York: Routledge.

Ferizaj, A. 2015. "Insight into Bosnia-and-Herzegovina's male and female survivors of wartime rape." Available at https://www.opendemocracy.net/en/5050/insight-into-bosnia -and-herzegovinas-male-and-female-survivors-of-wartime-rape/ (accessed January 2019).

Foucault, M. 2008. The birth of biopolitics: Lectures at the Collège de France, 1978-1979. New York: Palgrave Macmillan.

Funk, J. and Good N. 2017. Neizlječena trauma: Rad na ozdravljenju I izgradnji mira u BiH. Sarajevo: TPO Fondacija.

Gavey, N. 2005. Just sex: The cultural scaffolding of rape. Hove and Brighton: Routledge.

Goffman E. 1963. Stigma: Notes on the management of spoiled identity. Harmondsworth: Penguin Books.

Hayden, R. 2000. "Rape and rape avoidance in ethno-national conflicts: Sexual violence in liminilized states." American Anthropologist 102 (1): 27-41.

Helsinki Watch. 1993. War crimes in Bosnia-Herzegovina: New York: Helsinki Watch, a division of Human Rights Watch.

Henry, N. 2010. "The impossibility of bearing witness: Wartime rape and the promise of justice." Violence against Women 16 (10): 1098-1119.

Hesford, W. S. 1999. "Reading 'rape stories': Material rhetoric and the trauma of representation.” College English 62 (2): 192-221.

Husić, S., Šiljak I., Osmanović E., Đekić F., and Heremić L. 2014. Još uvijek smo žive! Istraživanje o dugoročnim posljedicama ratnog silovanja i strategijama suočavanja preživjelih u Bosni i Hercegovini. Medica: Zenica.

Jelin, E. 2003. State repression and the labors of memory. Minneapolis: University of Minnesota Press.

Kannenberg, R. L. 2003. Sociotherapy for sociopaths - Resocial group. Wisconsin: Healthcare Publications.

Kelly, L. 1988. Surviving sexual violence. New Jersey: Wiley.

Kidron, C. A. 2009. "Toward an ethnography of silence: The lived presence of the past in the everyday life of holocaust trauma survivors and their descendants in Israel." Current Anthropology 50 (1): 5-19.

La Capra, D. 1994. Representing the holocaust history, theory, trauma. Ithaca, NY: Cornell University Press.

Laumann, E. O. and Gagnon, J. 1995. Conceiving sexuality: Approaches to sex research in a postmodern world. New York: Routledge.

Lewis, L. J. 2006. "Sexuality, race and ethnicity.” In R. D. McAnulty and M. M. Burnette (Eds.), Sex and sexuality (229-265). Westport, CT: Praeger Publishers.

Leys, R. 2000. Trauma: A genealogy. Chicago: University of Chicago Press.

Link, B. and Phelan J. 2014. "Stigma power." Social Science and Medicine 103: 24-32. 
Lončar, M., Medvedev, V., Jovanović, N., and Hotujac, L. 2006. "Psychological consequences of rape on women in 1991-1995 war in Croatia and Bosnia and Herzegovina." Croatian Medical Journal 47 (1): 67-75.

Milroy, H. 2005. The Western Australian aboriginal child health survey: The social and emotional wellbeing of aboriginal children and young people. Perth: Curtin University of Technology and Telethon Institute for Child Health Research.

Mookherjee, N. 2006. "Remembering to forget: Public secrecy and memory of sexual violence in the Bangladesh war or 1971." Journal of Royal Anthropological Institute 12 (2): 433-450.

Parker, R. and Aggleton, P. 2003. "HIV and AIDS-related stigma and discrimination: A conceptual framework and implications for action." Social Science \& Medicine 57(1): $13-24$.

Pescosolido, B. and Martin, J. 2015. "The Stigma Complex." Annual Review of Sociology 41: 87-116.

Phelan, J.C., Link, B.G. and Dovidio, J.F. 2008. "Stigma and prejudice: One animal or two?" Social Science \& Medicine 67(3): 358-367.

Pilgrim, D. and McCranie, A. 2013. Recovery and mental health: A critical sociological account. Basingstoke, UK: Palgrave Macmillan.

Plummer, K. 1995. Telling sexual stories: Power, change and social worlds. New York: Routledge.

Quinn, D. M. and Chaudoir, S. R. 2009. "Living with a concealable stigmatized identity: The impact of anticipated stigma, centrality, salience, and cultural stigma on psychological distress and health." Journal of Personality and Social Psychology 97: 634-651.

Richters, A., Rutayisire, T., and Dekker, C. 2010. "Care as a turning point in sociotherapy: Remaking the moral world in post-genocide Rwanda." Medische Antropologie 22 (1): 93-108.

Ruff-O'Herne, J. 2008. 50 years of silence. London: William Heinemann.

Sayce, L. 1998. "Stigma, discrimination and social exclusion: What's in a word." Journal of Mental Health 7 (4): 331-343.

Schudson, M. 1997. "Lives, laws, and language: Commemorative versus noncommemorative forms of effective public memory." Communication Review 2 (1): 3-17.

Seifert, R. 1994. "War and rape: A preliminary analysis." In A. Stiglmayer (Ed.), Mass rape: The war against women in Bosnia-Herzegovina (54-72). Lincoln: University of Nebraska Press.

Simon, W. and Gagnon, J. H. 1986. "Sexual scripts: Permanence and change." Archives of Sexual Behavior 15 (2): 97-120.

Skjelsbaek, I. 2006. "Therapeutic work with victims of sexual violence in war and postwar: A discourse analysis of Bosnian experiences." Peace and Conflict Journal of Peace Psychology 12 (2): 93-118.

Skjelsabek, I. 2011. The political psychology of war rape: Studies from BosniaHerzegovina. New York: Routledge.

Smart, L. and Wegner, D. 1999. "Covering up what can't be seen: Concealable stigma and mental control." Journal of Personality and Social Psychology 77 (3): 474-486.

Smith, A. 2005. Conquest: Sexual violence and American Indian genocide. Boston: South End Press.

Sontag, S. 2003. Regarding the pain of others. New York: Picador.

Taussig, M. 1999. Defacement: Public secrecy and the labor of the negative. San Francisco: Stanford University Press. 


\section{Bibliography}

Tyler, I. 2013. Revolting subjects: Social abjection and resistance in neoliberal Britain. London: Zed.

Tyler, I. and Slater, T. 2018. "Rethinking the sociology of stigma." The Sociological Review Monographs 66 (4): 721-743.

Ullman, S. E. 2010. Talking about sexual assault: Society's response to survivors. Washington, DC: American Psychological Association.

UNFPA. 2016. Stigma against survivors of conflict related sexual violence in Bosnia and Herzegovina - Research Summary. Available: https://ba.unfpa.org/sites/default/ files/pub-pdf/UNFPA\%20Stigma\%20Short\%20ENG\%20FIN1_0.pdf (accessed 9 December 2019).

Vincent, B. and Durham, H. 2014. "Sexual violence in armed conflict: From breaking the silence to breaking the cycle." International Review of the Red Cross 96 (894): 427-434.

Vinitzky-Seroussi, V. and Teeger, C. 2010. "Unpacking the unspoken: Silence in collective memory and forgetting." Social Forces 88 (3): 1103-1122.

Vojnović, V. 2006. "Ne plači, bona, seno!.” Available at http:/www.popbo ks.com/artic le/2849 (accessed December 2017).

Vranić, S. 1996. Breaking the wall of silence: The voices of raped Bosnia. Zagreb: Izdanja Antibarbarus.

Wacquant, L. 2008. Urban outcasts: A comparative sociology of advanced marginality. Cambridge: Polity.

Waterston, A. and Rylko-Bauer, B. 2006. "Out of the shadows of history and memory: Personal family narratives in ethnographies of rediscovery." American Ethnologist 33 (3): 397-412.

Waynryb, R. 2001. The silence: How tragedy shapes talk. St Leonard's, N.S.W.: Allen \& Unwin.

White, H. 1992. "Historical emplotment and the problem of truth." In S. Friedlander (Ed.), Probing the limits of representation: Nazism and the 'final solution' (37-53). Cambridge, MA: Harvard University Press.

Whiteley, J. S. 1986. "Sociotherapy and psychotherapy in the treatment of personality disorder: Discussion paper." Journal of the Royal Society of Medicine 79: 721-725.

Whittier, D. K. and Simon, W. 2001. "The fuzzy matrix of 'My Type' in intrapsyhsic sexual scripting." Sexualities 4 (2): 139-165.

Wiseman, H. and Barber, J. P. 2008. Echoes of the trauma: Relational themes and emotions in chilren of holocaust survivors. Cambridge: Cambridge University Press.

Zerubavel, E. 2010. "The social sound of silence: Toward a sociology of denial." In BenZe'ev Efrat and Jay Winter (Eds.), Shadows of war: A social history of silence in the twentieth century (32-44). Cambridge: Cambridge University Press.

Åhäll, L. 2012. "Motherhood, myth and gendered agency in political violence." International Feminist Journal of Politics 14 (1): 103-120.

Ahmed, S. 2004. The cultural politics of emotions. Edinburgh: Edinburgh University Press.

Ahmetasevic, N. 2010. Women victims of sexual abuse in the Srebrenica genocide. Available at https://www.scribd.com/document/34161869/Women-Victims-of-SexualAbuse-in-the-Srebrenica-Genocide (accessed 8 August 2018).

Ahrens, C. E. 2006. "Being silenced: The impact of negative social reactions on the disclosure of rape." American Journal of Community Psychology 38 (3-4): 263-274.

Albanese, P. 2001. "Nationalism, war, and archaization of gender relations in the Balkans." Violence against Women 7 (9): 999-1023. 
Allen, B. 1996. Rape warfare: The hidden genocide in Bosnia-Herzegovina and Croatia. Minneapolis: University of Minnesota Press.

Arcana, J. 1983. Every mother's son: The role of mothers in the making of men. New York: Anchor Press.

Asfar, H. 2004. "Introduction: War and peace: What do women contribute." In H. Afshar and E. Deborah (Eds.), Development, women and war: Feminist perspectives (1-10). Oxford: Oxfam.

Bailey, A. 1996. "Mothering, diversity, and peace: Comments on Sara Ruddick's feminist maternal peace politics." In K. J. Warren and D. L. Cady, (Eds.), Bringing peace home (88-105). Bloomington: Indiana University Press.

Blee, K. 2004. "Positioning hate." Journal of Hate Studies 3 (1): 95-106.

Bolkovac, K. and Lynn, C. 2011. The whistleblower: Sex trafficking, military contractors, and one woman's fight for justice. New York: Palgrave Macmillan.

Bowcott, O. 2005. Report reveals shame of UN peacekeepers: Sexual abuse by soldiers 'must be punished. Available at https://www.theguardian.com/world/2005/mar/25/ unitednations (accessed August 9, 2018).

Bracewell, W. 1996. "Women, motherhood, and contemporary Serbian nationalism." Women's Studies International Forum 19 (1-2): 25-33.

Burchianti, M. E. 2004. "Building bridges of memory: The mothers of the Plaza de Mayo and the cultural politics of maternal memories." History and Anthropology 15 (2): 133-150.

Butler, J. 1993. Bodies that matter: On the discursive limits of "sex.". New York: Routledge.

Chodorow, N. 1978. The reproduction of mothering: Psychoanalysis and the sociology of gender. Berkeley: University of California Press.

Cockburn, C. 1998. The space between us: Negotiating gender and national identities in conflict. New York: Zed Books.

Cockburn, C. 2004. "The continuum of violence: A gender perspective on war and peace." In W. Giles and J. Hyndman (Eds.), Sites of violence: Gender and conflict zones (2444). Oakland: University of California Press.

Cogan, K. 2013. "The stitching mothers of Srebrenica v. Netherlands." American Society of International Law 104 (4): 884-890.

Collins, P. 1992. "Shifting the centre: Race, class and feminist theorizing about motherhood." In D. Bassin (Ed.), Representations and motherhood (371-388). New Haven: Yale University Press.

Copelon, R. 1995. "Gendered war crimes: Reconceptualizing rape in time of war." In: J. Peters and A. Wolper (Eds.), Women's rights, human rights: International feminist perspectives (197-214). New York: Routledge.

Danopoulos, C., Skandalis, K., and Isakovic, Z. 2012. "Women and children in the postcold war Balkans: Concerns and responses." In A. Schnabel and A. Tabyshalieva (Eds.), Defying victimhood: Women and post-conflict peacebuilding (145-165). New York: United Nations.

DiQuinzio, P. 1999. The impossibility of motherhood: Feminism, individualism and the problem of mothering. New York: Routledge.

Djurić-Kuzmanović, T., Drezgić, R., and Žarkov, D. 2008. "Gendered war, gendered peace: Violent conflicts in the Balkans and their consequences.” In D. Pankhurst (Ed.), Gendered peace: Women's struggles for post-war justice and reconciliation (265-291). New York: Routledge. 
Duhan Kaplan, L. 1994. "Woman as caretakers: An archetype that supports patriarchal militarism." In Karen J. Warren and Duane L. Cady (Eds.), Bringing peace home: Feminism, violence, and nature (165-174). Bloomington: Indiana University Press.

Edmonds, R. 2009. "Maternal thinking expanded: A psychologist's view." In A. O'Reilly (Ed.), Maternal thinking: Philosophy, politics, practice (204-216). Toronto: Demeter Press.

Einstein, Z. 1996. Hatreds: Racialized and sexualized conflicts in the 21st century. New York: Routledge.

El-Bushra, J. 2000. "Transforming conflict: Some thoughts on a gendered understanding of conflict processes." In S. Jacobs, R. Jacobson, and J. Marchbank (Eds.), States of conflict: Gender, violence and resistance (66-86). London: Zed Books.

Frank, W. A. 2003. The wounded storyteller: Body, illness and ethics. Chicago: University of Chicago Press.

Gallimore, R. 2017. "Genocide and the killing of motherhood, mothering and maternal body: Their rehabilitation in post-genocide Rwandan society." The International Journal of Conflict \& Reconciliation 3 (1): 1-35.

Hall, P. C. 1998. "Mothering mythology in the late 20th century: Science, gender lore, and celebrity narratives." Canadian Women Studies 18 (2/3): 59-63.

Hayes, S. 1998. The cultural contradictions of motherhood. Boston: Yale University Press.

Human Rights Watch Report. 1995. "The fall of Srebrenica and the failure of UN peacekeeping Bosnia and Herzegovina." Available at https://www.hrw.org/sites/defa ult/files/reports/ bosnia1095web.pdf (accessed 8 August 2018).

Jacobs, J. 2017. "The memorial at Srebrenica: Gender and the social meanings of collective memory in Bosnia-Herzegovina." Memory Studies 10 (4): 423-439.

Joy Green, F. 2004. "Feminist mothers: Successfully negotiating the tension between motherhood as institution and experience." In A. O'Reilly (Ed.), From motherhood to mothering: The legacy of Adrienne Rich's Of woman born (125-136). New York: SUNY Press.

Kašić, B., Prlenda, S., Petrović, J., and Slapšak, S. 2012. Feminist critical interventions. Thinking heritage, decolonising, crossings. Ljubljana, Zagreb, and Belgrade: Red Athena University Press.

Kinnvall, C. 2013. "Trauma and the politics of fear: Europe at the crossroads." In N. Demertzis (Ed.), Emotions in politics. Palgrave studies in political psychology series (143-166). London: Palgrave Macmillan.

Kleck, M. 2006. "Working with traumatized women." In M. Fischer (Ed.), Peacebuilding and civil society in Bosnia-Herzegovina. Ten years after Dayton (343-355). Münster: Lit-Verlag.

Klein, M. and Riviere, J. 1962. Love, hate, and reparation. London: The Hoghart Press.

Korac, M. 1998. "Ethnic nationalism, wars and the patterns of social, political and sexual violence against women: The case of post-Yugoslav countries." Identities Global Studies in Culture and Power 5 (2): 153-181.

Kumar, K. 2012. "Mass crimes and resilience of women: A cross-national perspective." In A. Schnabel and A. Tabyshalieva (Eds.), Defying victimhood: Women and post-conflict peacebuilding (79-95). New York: United Nations University Press.

Leydesdorff, S. 2007. "Stories from no land: The women of Srebrenica speak out." Human Rights Review 8 (3): 187-198.

Licht, S. and Drakulic, S. 1996. "When the word for peace was woman: War and gender in the Former Yugoslavia." In B. Wejnert and M. Spencer (Eds.), Women in postcommunism (111-139). Greenwich, CT/London: IAI Press. 
Lineman Nelson, H. 2001. Damaged identities: Narrative repair. Ithaca, NY: Cornell University Press.

Miklikowska, M. 2015. "Like parent, like child? Development of prejudice and tolerance towards immigrants." British Journal of Psychology 107 (1): 95-116.

Močnik, N. 2017. Sexuality after war rape: From narrative to embodied research. New York: Routledge.

Mulalic, M. 2011. "Women's NGOs and civil society building in Bosnia-Herzegovina." Epiphany 4 (1): 40-55.

Nikolić-Ristanović, V. 2000. Women, violence, and war: Wartime victimization of refugees in the Balkans. Budapest: Central European University Press.

O'Bryan, M., Fishbein H. D., and Neal, R. P. 2004. "Intergenerational transmission of prejudice, sex role stereotyping, and intolerance." Adolescence 39 (155): 407-426.

O'Reilly, A. (Ed.). 2004. Motherhood to mothering: The legacy of Adrienne Rich's of woman born. Albany: State University of New York Press.

O'Reilly, A. 2009. Maternal thinking: Philosophy, politics, practice. Toronto: Demeter Press.

Paechter, C. 2007. Being boys, being girls: Learning masculinities and femininities. Maidenhead, UK: Open University.

Pankov M., Mihelj, S., and Bajt, V. 2011. "Nationalism, gender and the multivocality of war discourse in television news." Media, Culture and Society 33 (7): 1043-1059.

Papić, Ž. 1979. "Društveni položaj žene - specifičnosti i teškoće utemeljenja problema." Žena 3: 106-116.

Papić, Ž. 1994. "Nationalism, patriarchy and war in ex-Yugoslavia." Women's History Review 3 (1): 115-117.

PBS. 2018. UN sex abuse scandal. Available at https:/www.pbs.org/wgbh/frontline/film/ un-sex-abuse-scandal/ (accessed 8 August 2018).

Popov-Momčinović, Z. 2013. Ženski pokret u Bosni I Herzegovini: Artikulacija jedne kontrakulture. Sarajevo: Sarajevski otvoreni centar, Centar za empirijska istraživanja religije u Bosni I Herzegovini, Fondacija CURE.

Pusić, V. 1976. "O nekim aspektima uloge feminizma u suvremenom društvu." Žena 3: $120-124$.

Ramanathapillai, R. 2006. "The politicizing of trauma: A case study of Sri Lanka." Peace and Conflict: Journal of Peace Psychology 12 (1): 1-18.

Ruddick, S. 1989. Maternal thinking: Toward a politics of peace. Boston, MA: Beacon Press.

Russell-Brown, S. 2003. "Rape as an act of genocide." Berkeley Journal of International Law 21 (2): 350-374.

Schirch, L. 2012. "Frameworks for understanding women as victims and peacebuilders." In A. Schnabel and A. Tabyshalieva (Eds.), Defying victimhood: Women and postconflict peacebuilding (48-76). New York: United Nations University Press.

Schnabel, A. and Tabyshalieva, A. (Eds.). 2012. Defying victimhood: Women and postconflict peacebuilding. Washington, DC: Brookings Institution Press.

Schnabel, A. and Tabyshalieva, A. 2012. "Forgone opportunities: The marginalization of women's contributions to post conflict peacebuilding." In A. Schnabel and A. Tabyshalieva (Eds.), Defying victimhood: Women and post-conflict peacebuilding (347). New York: United Nations University Press.

Sideris, T. 2001. "Rape in war and peace: Social context, gender, power and identity." In S. Meinjtes, A. Pillay, and M. Turshen (Eds.), Women in post-conflict transformation (142-157). London: Zed Books. 
Simić, O. 2009. "What remains of Srebrenica? Motherhood, transitional justice and yearning for the truth." Journal of International Women's Studies 10 (4): 220-236.

Simić, O. 2012. "Challenging Bosnian women's identity as rape victims, as unending victims: The 'other' sex in times of war." Journal of International Women's Studies 13 (4): 129-142.

Skjelsbaek, I. 2006. "Victim and survivor: Narrated social identities of women who experienced rape during the war in Bosnia-Herzegovina." Feminism and Psychology 16 (4): 373-403.

Škrgic-Mikulić, E. 2016. Bosnian war rape victims rue lost motherhood. Available at http:/ /www.balkaninsight.com/en/article/bosnian-war-rape-victims-rue-lost-motherhood-10 -20-2016 (accessed 1 August 2018).

Udruženje 'Pokret Majke enclave Srebrenica I Žepa. 2017. Available at http://www .enklave-srebrenica-zepa.org/

Walsh, M. 1997. Postconflict Bosnia-Herzegovina: Integrating women's special situation and gender perspectives in skills training and employment promotion programs. Geneva: ILO.

Warren, K. 1990. "The power and promise of ecological feminism.” Environmental Ethics 12 (3): 125-146.

Watson-Franke, M. 2004. "We have a mama but no papa: Motherhood in women-centred societies." In A. O'Reilly (Ed.), Motherhood to motherhing: The legacy of Adrienne Rich's of woman born (75-87). Albany: State University of New York Press.

Weiss, K. G. 2010. "Too ashamed to report: Deconstructing the shame of sexual victimization." Feminist Criminology 5 (3): 286-310.

Wenger, E. 1998. Communities of practice: Learning, meaning and identity. Cambridge: Cambridge University.

Yuval-Davis, N. 1997. Gender and nation. New York: Sage Publications.

Žarkov, D. 1995. "Gender, orientalism and the history of ethnic hatred in the Former Yugoslavia." In H. Lutz, A. Phoenix, and N. Davis Yuval (Eds.), Crossfires: Nationalism, racism, and gender in Europe (105-120). London: Pluto Press.

Žarkov, D. 2007. The body of war: Media, ethnicity, and gender in the break-up of Yugoslavia. Durham, NC: Duke University Press.

Zembylas, M. 2007a. "The politics of trauma: Empathy, reconciliation and peace education." Journal of Peace Education 4 (2): 207-224.

Zembylas, M. 2007b. "The affective politics of hatred: Implications for education." Intercultural Education 18 (3): 177-192.

Zraly, M., Rubin, S. E., and Mukamana, D. 2013. "Motherhood and resilience among Rwandan genocide-rape survivors." Ethos: Journal of the Society for Psychological Anthropology 41 (4): 411-439.

Arendt, H. 1958. The human condition. Chicago: University of Chicago Press.

Arendt, H. 2003. Responsibility and judgment. New York: Shocken Books.

Asman, A. 2011. Duga senka prošlosti: kultura sećanja i politika povesti. Beograd: Biblioteka XX vek.

Bar-On, D., Eland, J., Kleber, R. J., Krell, R., Moore, Y., Sagi, A., Soriano, E., Suedfeld, P., van der Velden, P. G., and van Ijzendoorn, M. H. 1998. "Multigenerational perspectives for understanding the development sequelae of trauma across generations." International Journal of Behavioral Development 22: 315-338.

Barsalou, J. and Baxter, V. 2007. The urge to remember: The role of memorials in social reconstruction and transitional justice. Available at https://www.usip.org/publications 
/2007/01/urge-remember-role-memorials-social-reconstruction-and-transitional-justi ce (accessed 19 December 2019).

Booth, J. 2001. "The unforgotten: Memories of justice." The American Political Science Review 95(4): 777-791.

Brison, S. 2002. Aftermath: Violence and the remaking of a self. Princeton: Princeton University Press.

Brown, R. 2003. "Measuring individual differences in the tendency to forgive: Construct validity and links with depression." Personality and Social Behavior Bulletin 29 (6): 759-771.

Brudholm, T. and Grøn, A. 2011. "Picturing forgiveness after atrocity." Studies in Christian Ethics 24(2): 159-170.

Brudholm, T. and Rosoux, V. 2009"The unforgiving: Reflections on the resistance to forgiveness after actrocity." Law and Contemporary Problems 72 (33): 33-49.

Card, C. 1996. "Rape as a weapon of war." Hypatia, Special Issue: Women and Violence 11 (4): 5-18.

Card, C. 2002. The atrocity paradigm: A theory of evil. Oxford: Oxford University Press.

Caruth, C. 1995. Trauma: Explorations in memory. Baltimore, MD: JHU Press.

Cerney, M.S. 1988. "“If only ..." remorse in grief therapy." Psychotherapy Patient 5: 235-248.

Cosgrove, L. and Konstam, V. 2008. Forgiveness and forgetting: Clinical implications for mental health counselors. Journal of Mental Health Counseling 30 (1): 1-13.

Danieli, Y. 1981. "Differing adaptational styles in families of survivors of the Nazi Holocaust." Child Today 10 (5): 6-10.

Danieli, Y. 1998. "Introduction: History and conceptual foundations.” In Y. Danieli (Ed.), International handbook of multigenerational legacies of trauma (1-17). New York: Plenum Press.

Derrida, J. 2000. “On forgiveness." Studies in Practical Philosophy 2 (2): 81-102.

Felman, S. 1995. Testimony: Crises of witnessing in literature, psychoanalysis and history. New York: Routledge.

Halbwachs, M. 1992. On collective memory. Chicago, IL: University of Chicago Press.

Herman, J. 1992. Trauma and recovery. The aftermath of violence-From domestic abuse to political terror. New York: Basic Books.

Hirsch, M. 1999. "Projected memory: Holocaust photographs in personal and public fantasy." In M. Bal, J. V. Crewe, and L. Spitzer (Eds.), Acts of memory: Cultural recall in the present (3-23). New Hampshire, New England: University Press of New England.

Hobsbawn, E. and Ranger, T. 1983. The invention of tradition. Cambridge: Cambridge University Press.

Holmgren, M. R. 1993. "Forgiveness and the intrinsic value of persons." American Philosophical Quarterly 30 (4): 341-352.

Kaplan, L. J. 1995. No voice is ever wholly lost: An explorations of the everlasting attachment between parent and child. New York: Simon \& Schuster.

Kolnai, A. 1973. "Forgiveness." Proceedings of the Aristotelian Society 74 (91): 106.

Kristeva, J. and Rice, A. 2002. "Forgiveness: An interview." PMLA 117 (2): 278-295.

Laub, D. 1995. "Truth Sand testimony: The process and the struggle." In C. Caruth (Ed.), Trauma: Explorations in memory (45-61). Baltimore, MD: JHU Press.

Looney, A. T. 2015. Vladimir Jankélévitch: The time of forgiveness. New York: Fordham University Press.

May Schott, R. 2004. "The atrocity paradigm and the concept of forgiveness." Hypatia: A Journal of Feminist Philosophy 19 (4): 204-211. 


\section{Bibliography}

Mendelhoff, D. 2009. "Trauma and vengeance: Assessing the psychological and emotional effects of post-conflict justice." Human Rights Quarterly 31 (3): 592-623.

Middleton, D. and Derek, E. 1990. Inquiries in social construction. Collective remembering. Thousand Oaks, CA: Sage Publications.

Minow, M. 1998. Between vengeance and forgiveness: Facing history after genocide and mass violence. Boston: Beacon Press.

Ricoeur, P. 1973. Memory, history, forgetting. Chicago: University of Chicago Press.

Thompson, L. Y., Snyder, C. R., Hoffman, L., Michael, S. T., Rasmussen, H. N., Billings, L. S., Heinze, L., Neufeld, J. E., Shorey, H. S., Roberts, J. C., and Roberts, D. E. 2005. "Dispositional forgiveness of self, others, and situations." Journal of Personality 73 (2): 313-359.

Thompson, P. 2009. "Family myth, models, and denials in the shaping of individual life paths." In P. Thompson and D. Bertaux (Eds.), Between generations: Family models, myths and memories (13-38). London: Transaction Publishers.

Tonkin, E. 1992. Narrating our pasts: The social construction of oral history. Cambridge: Cambridge University Press.

Tota, A. L. 2006. Public memory and cultural trauma. The Public 13 (3): 81-94.

Sagi-Schwartz, A., van Ijzendoorn, M., Grossmann, K. E., Grossmann, K., and KorenKarie, N. 2003. "Attachment and traumatic stress in female holocaust child survivors and their children." American Journal of Psychiatry 160: 1086-1092.

Sontag, S. 2003. Regarding the pain of others. New York: Picador.

Svašek, M. 2005. "The politics of chosen trauma: Expellee memories, emotions and identities." In K.E. Milton and M. Svašek (Eds.), Mixed emotions: Anthropological studies of feeling (195-214). Oxford: Berg.

van der Veer, G. 1998. Counselling and therapy with refugees and victims of trauma: Psychological problems of victims of war, torture and repression. New Jersey: Wiley.

Volkan, V.D. 1997. "Transgenerational transmissions and chosen traumas: An aspect of large-group identity." Group Analysis 34(1): 79-97.

Volkan, V. D. 2001. "Transgenerational transmissions and chosen traumas: An aspect of large-group identity." Group Analysis 34 (1): 79-97.

Webb, J. R., Bumgarner, D. J., Conway-Williams, E., Dangel, T., and Hall, B. B. 2017. "A consensus definition of self-forgiveness: Implications for assessment and treatment." Spirituality in Clinical Practice 4 (3): 216-227.

Weingarten, K. 2003. Common shock: Witnessing violence every day: How we are harmed, how we can heal. New York: Dutton Books.

Zembylas, M. 2007. "The politics of trauma: Empathy, reconciliation and education." Journal of Peace Education 4(2): 207-224.

Ahonen, S. 2012. Coming to terms with a dark past. How post-conflict societies deal with history. Frankfurt: Peter Lang.

Ahonen, S. 2014. "Education in post-conflict societies." Historical Encounters 1 (1): 75-87.

Akman, K. B. 2015. "Sociotherapy as a contemporary alternative." Bangladesh E-Journal of Sociology 12 (1): 9-16.

Asavei, M. A. 2019. "The art and politics of imagination: Remembering mass violence against women." Critical Review of International Social and Political Philosophy. 22 (5): 618-636. doi: 10.1080/13698230.2019.1565704.

Auerbach, Y. 2009. "The reconciliation pyramid: A narrative based framework for analysing identity conflicts." Political Psychology 30 (2): 291-318. 
Auerhahn, N. and Laub, D. 1998. "The primal scene of atrocity: The dynamic interplay between knowledge and fantasy of the Holocaust in children of survivors." Psychoanalytic Psychology 15 (3): 360-377.

Bajramović, S. 2018. Hierarchical sisterhood. Supporting women's peacebuilding through Swedish aid to Bosnia-Herzegovina 1993-2013. Örebro: Örebro University Print.

Bal, M. 2001. Looking in: The art of viewing. Amsterdam: Gordon and Breach.

Bar-On, D. 1999. The indescribable and the undiscussable: Reconstructing human discourse after trauma. Budapest, Hungary: Central European University Press.

Bar-On, D. 2006. Tell your life story: Creating dialogue among Jews and Germans, Israelis and Palestinians. Budapest: Central European University Press.

Barry, K. 1979. Female sexual slavery. Englewood Cliffs, NJ: Prentice-Hall.

Bekerman, Z. and Zembylas, M. 2011. Teaching contested narratives: Identity, memory and reconciliation in peace education and beyond. New York: Cambridge University Press.

Berry, M. E. 2017. "Barriers to women's progress after atrocity: Evidence from Rwanda and Bosnia-Herzegovina." Gender and Society 31 (6): 830-853.

Bertaux, D. and Thompson, P. 2005. "Introduction." In D. Bertaux and P. Thompson (Eds.), Between generations: Family models, myths and memories (2-12). New Jersey: Transaction Publishers.

Bieber, F. 2002. "Aid dependency in Bosnian politics and civil society: Failures and successes of post-war peacebuilding in Bosnia-Herzegovina." Croatian International Relations Review 8 (26): 25-29.

Brock-Utne, B. 1985. Educating for peace: A feminist perspective. New York: Pergamon Press.

Bloomfield, D. 2006. On good terms: Clarifying reconciliation. Berlin: Berghoff Foundation.

Brown, M., Boege, V., Clements, K., and Nolan, A. 2010. "Challenging state-building as peacebuilding: Working with hybrid political orders to build peace." In O. Richmond (Ed.), Palgrave advances in peacebuilding: Critical developments and approaches (99-115). London: Palgrave.

Burt, M. R. 1980. "Cultural myths and supports for rape." Journal of Personality and Social Psychology 38 (2): 217-230.

Clark, N. J. 2016. "Working with survivors of war rape and sexual violence fieldwork reflections from Bosnia-Hercegovina." Qualitative Research 17 (4): 424-439.

Cole, E. A. and Barsalou, J. 2006. Unite or divide? The challenges of teaching history in societies emerging from violent conflict. Washington, DC: United States Institute of Peace.

Crocker, J., Major, B., and Steele, C. 1998. "Social stigma." In D. T. Gilbert and S. T. Fiske (Eds.), The handbook of social psychology (504-553). Boston, MA: McGraw-Hill.

D'Adamo, L. and Fallace, T. 2011. "The multigenre research project: An approach to developing historical approach." Social Studies Research and Practice 6 (1): 75-88.

Das, V. 2007. Life and words. Violence and the descent into the ordinary. Oakland: University of California Press.

Davis, O., Yeager, E., and Foster, S. (Eds.). 2001. Historical empathy and perspective taking in the social studies. New York: Rowman and Littlefield.

Davies, W. 2016. The happiness industry: How the government and big business sold us wellbeing. London: Verso. 


\section{Bibliography}

Davies, W. 2017. "On mental health, the royal family is doing more than our government." Available at https://www.theguardian.com/commentisfree/2017/apr/20/mental-healthroyal-family-government-children-illness (accessed 8 March 2019).

Delić, A. and Avdibegović, E. 2016. "Shame and silence in the aftermath of war rape in Bosnia and Herzegovina: 22 years later." Available at https://www.researchgate.net/p ublication/293 815848_Shame_and_Silence_in_the_aftermath_of_War_Rape_in_Bos nia_and_Herzegovina_22_years_later (accessed 9 March 2019).

Eastmond, M. 2010. "Reconciliation, reconstruction and everyday life in war torn societies." Focaal: Journal of Global and Historical Anthropology 57: 3-16.

Edelson, M. 1970. Sociotherapy and psychotherapy. Chicago: University of Chicago Press.

Francis, D. 2002. People, peace and power: Conflict transformation in action. London: Pluto Press.

Freire, P. 1970. Pedagogy of the oppressed. New York: Herder and Herder.

Funk, J. and Good, N. 2017. Neizlječena trauma: Rad na ozdravljenju I izgradnji mira u $\mathrm{BiH}$. Sarajevo: TPO Fondacija.

Gavey, N. 2005. Just sex: The cultural scaffolding of rape. Hove and Brighton: Routledge.

Goffman, E. 1963. Stigma: Notes on the management of spoiled identity. Harmondsworth: Penguin Books.

Halilovich, H. 2015. "Long-distance mourning and synchronised memories in a global context: Commemorating Srebrenica in diaspora." Journal of Muslim Minority Affairs 35 (3): 410-422.

Helms, E. 2014. "Rejecting Angelina: Bosnian war rape survivors and the ambiguities of sex in war." Slavic Review 73 (3): 612-634.

Hesford, W. S. 1999. "Reading 'rape stories': Material rhetoric and the trauma of representation." College English 62 (2): 1992-221.

Hirsch, M. 2012. The Generation of postmemory: Writing and visual culture after the Holocaust. New York: Columbia University Press.

Hoogenbom, D. and Vieille, S. 2010. "Rebuilding social fabric in failed states: Examining transitional justice in Bosnia." Human Rights Review 11 (2): 183-198.

Husić, S., Šiljak, I., Osmanović, E., Đekić, F., and Heremić, L. 2014. Još uvijek smo žive! Istraživanje o dugoročnim posljedicama ratnog silovanja i strategijama suočavanja preživjelih u Bosni i Hercegovini. Medica: Zenica.

Igreja, V. 2008. "Memories as qeapons: The politics of peace and silence in post-civil war Mozambique." Journal of Southern African Studies 34 (3): 539-556.

Israfilova, F. and Khoo-Lattimore, C. 2018. "Sad and violent but I enjoy it: Children's engagement with dark tourism as an educational tool." Tourism and Hospitality Research 1: 1-10.

Jacobs, J. 2016. "The memorial at Srebrenica: Gender and the social meanings of collective memory in Bosnia-Herzegovina." Memory Studies 10 (4): 423-439.

Jansen, S. 2013. "If reconciliation is the answer are we asking right questions?" Studies in Social Justice 7 (2): 229-243.

Jones, B., Jeffrey, A., and Jakala, M. 2012. "The 'transitional citizen': Civil society, political agency and hopes for transitional justice in Bosnia and Herzegovina." InO. Simićand Z. Volčić (Eds.), Transitional Justice and Civil Society in the Balkans (87103). New York: Springer.

Josse, E. 2010. “"They came with two guns': The consequences of sexual violence for the mental health of women in armed conflicts." International Review of the Red Cross 92 (877): 177-195. 
Kannenberg, R. L. 2003. Sociotherapy for sociopaths - Resocial group. Dublin: Premier Publishing.

Kaplan, L. 1996. No voice is ever wholly lost. An exploration of the everlasting attachment between parent and child. New York: Simon \& Schuster.

Kappler, S. 2013. "Peacebuilding and lines of friction between imagined communities in Bosnia-Herzegovina and South Africa." Peacebuilding 1 (3): 349-364.

Karge, H. and Batarilo, K. 2008. "Reform in the field of history in education Bosnia and Herzegovina: Modernization of history textbooks in Bosnia and Herzegovina: From the withdrawal of offensive material from textbooks in 1999 to the new generation of textbooks in 2007/2008." Available at http://repository.gei.de/bitstream/handle/11428 /264/Karge_Batarilo_Reform.pdf.

Kelly, L. 1988. Surviving sexual violence. New Jersey: Wiley.

Klein, E. 1998. "International aspects of the conflict in the Former Yugoslavia." In Y. Danieli (Ed.), International handbook of multigenerational legacies of trauma (279295). New York: Plenum Press.

Knaus, G. and Martin, F. 2003. "Travails of the European Raj." Journal of Democracy 14 (3): $60-74$.

Korostelina, K. 2013. History education in the formation of social identity. New York: Palgrave MacMillian.

Lederach, J. P. 1997. Building peace: Sustainable reconciliation in divided societies. Washington: Institute of Peace Press.

Lengel, L. 2018. "Mediated memory work and resistant remembering of wartime sexual violence, 1992-1995." Feminist Media Studies 18 (2): 325-328.

Link, B. and Phelan, J. 2014. "Stigma power." Social Science and Medicine 103: 24-32.

Lončar, M., Medvedev, V., Jovanović, N. and Hotujac, L. 2006. "Psychological consequences of rape on women in 1991-1995 war in Croatia and Bosnia and Herzegovina." Croatian Medical Journal 47 (1): 67-75.

Mandi, F. D., Williams, S. L., Rife, S. C., and Cantrell, P. 2015. "Examining cultural, social, and self-related aspects of stigma in relation to sexual assault and trauma symptoms." Violence Against Women 21 (5): 598-615.

Mannergren Selimovic, J. 2013. "Making peace, making memory: Peacebuilding and politics of remembrance at memorials of mass atrocities." Peacebuilding Journal 1 (3): 334-348.

Mannheim, K. 1972. "The problems of generations." In Karl Mannheim (Ed.), Essays in the sociology of knowledge (276-322). London: Routledge.

McCully, A. 2012. "History teaching, conflict and the legacy of the past." Education, Citizenship and Social Justice 7 (2): 145-159.

McGrattan, C. and Stephen Hopkins. 2016. "Memory in post-conflict societies: From contention to integration?" Ethnopolitics 16 (5): 488-499.

Mobekk, E. 2005. "Transitional justice in post-conflict societies. Approaches to reconciliation." In A. Ebnother and P. Fluri (Eds.), After intervention: Public security management in post-conflict societies. (261-292) Geneva: Geneva Centre for the Democratic Control of Armed Forces.

Murphy, K. and Gallagher, T. 2009. "Reconstruction after violence: How teachers and schools can deal with the legacy of the past." Perspectives in Education 27 (2): 11.

Nordquist, K. 2017. Reconciliation as politics: A concept and its practice. Eugene, OR: Pickwick Publications.

O’Reilly, M. 2012. "Muscular interventionism.” International Feminist Journal of Politics 14 (4): 529-548. 


\section{Bibliography}

Orford, A. 2003. Reading humanitarian intervention: Human rights and the use of force in international law. Cambridge: Cambridge University Press.

Parent, G. 2016. "Local peacebuilding, trauma, and empowerment in Bosnia-Herzegovina." Peace and Change 41 (4): 510-538.

Paris, R. 2004. At war's end: Building peace after civil conflict. Cambridge: Cambridge University Press.

Parker, R. and Aggleton, P. 2003. "HIV and AIDS-related stigma and discrimination: A conceptual framework and implications for action." Social Science and Medicine 57 (1) 13-24.

Pašalić-Kreso, A. 2008. "The war and post-war impact on the educational system of Bosnia and Herzegovina." International Review of Education 54 (3): 353-374.

Pavlowitch, S. K. 2004. "History education in the Balkans: How bad is it?" Journal of Southern Europe and the Balkans 6 (1): 63-68.

Pescosolido, B. and Martin, J. 2015. "The stigma complex.” Annual Review of Sociology 41: 87-116.

Pilgrim, D. and McCranie, A. 2013. Recovery and mental health: A critical sociological account. Basingstoke, UK: Palgrave Macmillan.

Quinn, D. M. and Chaudoir, S. R. 2009. "Living with a concealable stigmatized identity: The impact of anticipated stigma, centrality, salience, and cultural stigma on psychological distress and health." Journal of Personality and Social Psychology 97: 634-651.

Richetrs, A., Rutayisire, T., and Dekker, C. 2010. "Care as a turning point in sociotherapy: Remaking the moral world in post-genocide Rwanda." Medische Antropologie 22 (1): 93-108.

Richmond, O. P. 2004. "The globalization of responses to conflict and the peacebuilding consensus." Cooperation and Conflict 39 (2): 129-150.

Sayce, L. 1998. "Stigma, discrimination and social exclusion: What's in a word." Journal of Mental Health 7 (4): 331-343.

Schaap, A. 2008. "Reconciliation as ideology and politics." Constellations: An International Journal of Democratic and Critical Theory 15 (2): 249-264.

Schank, R. C. 1990. Tell me a story: A new look at real and artificial memory. New York: Macmillan.

Simić, O. 2009. "What remains of Srebrenica? Motherhood, transitional justice and yearning for the truth.” Journal of International Women's Studies 10 (4): 220-236.

Simić, O. 2018. Silenced victims of wartime sexual violence. New York: Routledge.

Simić, O. and Volčić, Z. 2014. "In the land of wartime rape: Bosnia, cinema and reparation." Griffith Journal of Law and Human Dignity 2 (2): 377-401.

Skjelsbaek, I. 2006. "Therapeutic work with victims of sexual violence in war and postwar: A discourse analysis of Bosnian experiences." Peace and Conflict Journal of Peace Psychology 12 (2): 93-118.

Smith, A. 2011. Education and peacebuilding: From "conflict-analysis" to "conflict transformation”? Retrieved from http://uir.ulster.ac.uk/19794/ (accessed 27 February 2019).

Smart, L. and Wegner, D. 1999. "Covering up what can't be seen: Concealable stigma and mental control." Journal of Personality and Social Psychology 77 (3): 474-486.

Solga, K. 2006. "Rape's metatheatrical return: Rehearsing sexual violence among the early moderns." Theatre Journal 58 (1): 53-72.

Stiglmayer, A. 1994. "The war in the Former Yugoslavia.” In A. Stiglmayer (Ed.), Mass rape: The war against women in Bosnia-Herzegovina (1-34). Lincoln: University of Nebraska Press. 
Thaler, M. 2018. Naming violence: A critical theory of genocide, torture, and terrorism. New York: Columbia University Press.

Tyler, I. 2013. Revolting subjects: Social abjection and resistance in neoliberal Britain. London: Zed.

Tyler, I. and Slater, T. 2018. "Rethinking the sociology of stigma." The Sociological Review Monographs 66 (4): 721-743.

UN. 2017. "Shame, stigma integral to logic of sexual violence as war tactic, special adviser tells security council, as speakers demand recognition for survivors." Available at https ://www.un.org/press/en/2017/sc12819.doc.htm (accessed 8 March 2019).

Vinitzky-Seroussi, V. and Teeger, C. 2010. "Unpacking the unspoken: Silence in collective memory and forgetting." Social Forces 88 (3): 1103-1122.

Wacquant, L. 2008. Urban outcasts: A comparative sociology of advanced marginality. Cambridge: Polity.

Whiteley, J. S. 1986. "Sociotherapy and psychotherapy in the treatment of personality disorder: Discussion paper." Journal of the Royal Society of Medicine 79: 721-725.

Winter, J. 2010. “Thinking about silence.” In E. Ben-Zeev, R. Ginio, and J. Winter (Eds.), Shadows of war: A social history of silence in the twentieth century (3-31). New York: Cambridge University Press.

World Vision. 2016. No shame in justice addressing stigma against survivors to end sexual violence in conflict zones. Available at https://assets.worldvision.org.uk/files/7214/ 5806/4579/Stigma_Summary_Report.pdf (accessed 9 March 2019).

Yordanova, K. 2015. “The second generation's imagery of the Bosnian war (1992-1995)." Anthropology of East Europe Review 33 (1): 70-86. 